\title{
The USE OF Therapeutic Cloning IN TRANSPLANTATIONS: An ARistotelian Perspective
}

\author{
Christos Labrou
}

\begin{abstract}
We do not think, however, of the purposes to which we aspire, but of the means that will guide us to their accomplishment. A doctor, for instance, does not think about whether he will cure the patient, neither does an orator think about whether he will convince his audience, nor a politician about whether he will assure the good function of laws... Everyone, after they have set and determined a purpose, examine the ways and means with which, this can be achieved. ${ }^{1}$
\end{abstract}

Aristotle, Nechomachean Ethics, 1112b 7-16

\begin{abstract}
Therapeutic cloning for transplantations is one of the most complex issues in Bioethics. This is because it involves two of the most controversial subjects in today's medicine: cloning and transplantations. Although therapeutic cloning is a modern issue in the scope of transplantations, we consider Aristotle's contribution to be of high importance. On a first level, we will describe the modern phenomenon of therapeutic cloning, concerning the medical technique itself, its aim, its use in transplantations and its core legal and political aspects. On a second level, the depth of Aristotelian concepts of nature, art and their interrelationship will enlighten crucial aspects of our discussion, concerning human health and medicine. On a third level, Aristotle's concept of matter will constitute the basis for the solution of the ethical problems of transplantation through therapeutic cloning. On a fourth level, the Aristotelian concept of practical wisdom, considered as a part of Politics, will provide us with practical guidance as to how decision-making and legislation should be utilised to support the appropriate use of therapeutic cloning; thus, it will become clear that it is a moral-law and moral-politic issue. Finally, we will address the moral objections to therapeutic cloning, establishing some fundamental elements for the building of consensus between different countries on this subject.
\end{abstract}

\section{A. INTRODUCTION}

Cloning has always been a controversial issue. The complexity of the subject is evidenced by widespread public ignorance of the entire area of therapeutic, as distinct from reproductive, cloning. Indeed, one could argue that Dolly, perhaps the reproductive cloning's most well-known

\footnotetext{
${ }^{1}$ Author's translation.
} 
child, is more famous than the general scientific area of therapeutic cloning.

This essay aims to show that therapeutic cloning can provide significant solutions to fundamental problems of human health, and therefore rightly deserves to gain its proper acknowledgement by society. More specifically the essay is centred on three main questions. Firstly, should therapeutic cloning be allowed in principle, and, if so, why and under what conditions? Secondly, is the use of therapeutic cloning in transplantations the appropriate means of achieving health goals, and if so, why? Finally, to what extent can therapeutic cloning be conceptualized as a political issue - or, in other words, as a matter of public policy? In order to answer these questions we will use certain aspects of Aristotelian philosophy for the following reasons: firstly, because Aristotle's theory of human nature provides the conceptual tools that assist in resolving the afore-mentioned fundamental questions, and secondly because Aristotle's political philosophy, provides, in our opinion, the appropriate means for exploring the practical dimension of this subject.

The current debate is framed around the conflict between the benefit of health that derives from therapeutic cloning and the moral objections which are raised to the use of the method. This leads to a lack of consensus between countries worldwide about whether therapeutic cloning should be allowed or not, and it is this gap we aim to bridge with this essay. It will hereby be submitted that therapeutic cloning should be allowed, because the use of it in transplantations will be invaluable as a means for saving human lives; however, therapeutic cloning can only be considered to be an applicable method and a viable therapeutic option if we focus on the correct way of its use. We will show why therapeutic cloning is the appropriate medical technique to achieve the goal of health and we will underline the role of politics in formulating a framework for decision making and legislation about the subject.

This essay is divided into two parts. The first part is a synopsis of the modern phenomenon of cloning and transplantations. Firstly, we will see how cloning is defined and how it is divided into two categories, namely reproductive and therapeutic cloning. The techniques and aims of each will be described, justifying our focus on therapeutic cloning in the 
remainder of this essay. Then, we will talk about transplantations and about how they are connected to therapeutic cloning. We will discuss which problems can be solved by the combination of these two methods, and the benefits of this approach. Finally, we will comment on the dead end reached internationally after a number of debates regarding therapeutic cloning, evidenced by the lack of consensus between countries as to whether or not to permit this technique.

In the second part of our essay we will examine the problématique of therapeutic cloning through Aristotelian philosophy. Firstly, we will see how the understanding of nature will help us connect it with medicine. Secondly, after we consider that medicine belongs to the general genus of arts, we explore its interaction with human nature, emphasizing their common goal, which is health. Thirdly, we will show how matter constitutes the link between human nature and therapeutic cloning (as a method of medicine) and highlight the solution that this provides on the subject of transplantations. Fourthly, we will discuss the Aristotelian concept of practical wisdom as an inseparable part of politics, in order to provide our study with a practical dimension. This will be done by showing how politics should guide medicine in the field of therapeutic cloning in transplantations. Finally, we will address the moral objections concerning therapeutic cloning, using the results of our research in the previous parts.

\section{B. The modern Problématique of Therapeutic Cloning and Transplantations}

\section{Cloning}

Cloning currently stands as one of the greatest human accomplishments, which has sown dissension among the universal intelligentsia, scientists and politicians. In many nations and on the level of international law, legislative remedies for this issue are being urgently sought. The increasing body of legal, philosophical, medical and other research on the cloning problématique, underscores the importance of this issue. According to Sanchez: "Cloning is raising new challenges and 
opportunities and the ethical, legal, social and health issues need to be monitored'.2

Etymologically, 'cloning' derives from the Greek 'klon' meaning 'twig', referring to the procedure by which the cutting and implanting of a branch from a plant can yield a similar plant. In 2012, we have the 60th anniversary of the first use of somatic cell nuclear transfer (SCNT) and the creation of the first frog-clone by Briggs and $\mathrm{King}^{4}$, since when many other animal species have also been created using this procedure.

To begin with, we can say that cloning is 'the asexual production of genetically identical organisms or cell lines'. ${ }^{5}$ Cloning 'consists either of the use of somatic cell nuclear transfer (SCNT) into an ovum, from which the nucleus has been extracted, or of production of colonies of genetically identical cells with successive divisions of a single cell' ${ }^{6}$, just as in the case of homozygous twins. ${ }^{7}$ Of the two, the former method is the one that will concern us in the present article.

Taking a somatic cell from an adult and implanting its nucleus into an ovum, we create an embryo, which has the same genetic material as the donor of the nucleus. This embryo will comprise the basis, either for the creation of a self-sufficient organism, or for the creation of tissues and organs. The cells used in the cloning technique are called stem cells. Stem cells contain the entire genetic information of an organism. Cloning problématique is based on the totipotency and the pluripotency of stem cells. As Savulescu observes:

${ }^{2}$ L.R. Sanchez-Sweatman, 'Reproductive cloning and human health: an ethical, international, and nursing perspective', International Nursing Review, (2001) Vol. 74, Issue 137.

${ }^{3}$ Steven Garrard Post (ed) Encyclopedia of Bioethics, (3rd ed.,MacMillan Reference USA, 2004), A to C, Vol 1, 451.

${ }^{4}$ A Meissner, R Jaenisch, 'Mammalian Nuclear Transfer', Developmental Dynamics, (2006) Vol. 235, Issue 92460.

${ }^{5}$ Sanchez-Sweatman (n 2) 29.

6 A Manitakis, 'The legal ban of cloning and the right to reproduction' A.L.N.G., Scientific Conference on Artificial fertilization and genetics: the moral-law dimension, Ant. N Sakkoula, (2003) 37; G Saint-Paul, 'Economic aspects of human cloning and reprogenetics', Economic policy, (2003) Vol. 18, Issue 36 78; SanchezSweatman (n 2) 29.

7 J A Byrne and J B Gurdon, 'Commentary on human cloning', Differentiation (2002) Issue $69,154$. 
Stem cells have the ability to mature into different mature cell types. Totipotent stem cells are cells with the potential to form a complete human being if placed in a uterus. They are early embryos. Pluripotent stem cells are very immature stem cells with the potential to develop into any of the mature cell types in the adult (liver, lung, skin, blood, etc), but cannot by themselves form a complete human being if placed in a uterus. ${ }^{8}$

Cloning is divided into two kinds, reproductive and therapeutic cloning. We will examine each of them separately in the following sections.

\section{Reproductive Cloning}

Reproductive cloning is 'the asexual production of identical fetuses from a single cell ${ }^{9}$ in order to produce human beings. ${ }^{10}$ Making use of the totipotency of stem cells, "the objective of reproductive cloning is to produce a child genetically identical to an individual'. ${ }^{11}$ Reproductive cloning is based on the technique of nuclear transfer, meaning the replacement of the ovum's nucleus by the nucleus of an embryonic or adult somatic cell. Afterwards, all the necessary procedures are followed to trigger the division of the ovum (usually intense electric shock), until it reaches a sufficient level of development for the embryo to be transferred into the uterus that is going to gestate it. ${ }^{12} \mathrm{We}$ can talk about reproductive cloning only in the context of implantation of the fertilized ovum into the uterus.

A great number of mammals born so far through reproductive cloning present severe and unforeseeable health disorders. As Byrne and Gurdon note 'the majority of scientific opinion is opposed to the reproductive cloning of humans in view of the developmental, morphological, and physiological problems observed in mammals that had been cloned'. ${ }^{13}$ As a result, reproductive human cloning raises numerous ethical concerns such as the physical and psychological harm

\footnotetext{
${ }^{8} \mathbf{J}$ Savulescu, 'The ethics of cloning and creating embryonic stem cells as a source of tissue for transplantation: time to change the law in Australia', Aust NZ J Med, (2000) Volume 30, Issue 4492.

${ }^{9}$ Sanchez-Sweatman (n 2) 29.

${ }^{10}$ Saint-Paul (n 6) 76.

${ }^{11}$ Byrne, Gurdon (n 7) 154.

${ }^{12}$ Garrard Post (n 3) 451.

${ }^{13}$ Byrne, and Gurdon (n 7) 155.
} 
to the clone. ${ }^{14}$ Taking this point as a starting point, any attempt to apply this method on humans would amount to treating both the woman and the potential 'child-clone' as guinea pigs. ${ }^{15}$ Hence, international scientific opinion currently considers the application of reproductive cloning to human beings as problematic, on both medical and ethical grounds.

We observe that the 'necessary guarantees of scientific security' 16 are not in place for the safe and well-monitored application of the method. At the same time, the current standard of our knowledge and the success rates of the technique cannot be considered sufficient to justify the creation of a human being through reproductive cloning. Moreover, issues of protection of human dignity, of health and life are raised. All the above arguments militate in favour of the prohibition of reproductive cloning internationally, considering it to be an experiment with incalculable results for human beings.

\section{Therapeutic Cloning}

Therapeutic cloning follows the method of nuclear transfer (SCNT) with the difference that the fertilized ovum is not implanted into the uterus for gestation, but is isolated. The procedure is afterwards continued in vitro. Then, 'as the embryo grows, cells gradually 'differentiate' themselves into tissue specific types. These undifferentiated stem cells can be used in therapeutic cloning'. ${ }^{17}$ The goal of therapeutic cloning is the creation of tissues and organs, for the ultimate purpose of their transplantation into humans.

According to Attala, 'therapeutic cloning, where the nucleus from a donor cell is transferred into an enucleated oocyte, in order to extract pluripotent embryonic stem cells, offers a potentially limitless source of cells for tissue engineering applications'. ${ }^{18}$ Therapeutic cloning can be used in 'reparation, regeneration and development of human tissue and

\footnotetext{
${ }^{14}$ Sanchez-Sweatman (n 2) 29.

${ }^{15}$ H M Warnock, 'Ethics and biotechnology', Science and Society, (2001) Vol 5-6 153; J R Hill, 'Abnormal in utero development of cloned animals: implications for human cloning', Differentiation, (2002) Volume 69, Issue 4-5 175.

${ }^{16} \mathrm{~S}$ Vlachopoulos, Cloning in Greek legistlation - From Adam to Dolly: the end of the traditional way of reproduction, (Ant. N. Sakkoula, 2000) 81.

${ }^{17}$ Saint-Paul (n 6) 78.

${ }^{18}$ A Atala, 'Engineering tissues, organs and cells', Journal of Tissue Engineering and Regenerative Medicine, (2007) Vol 1, Issue 283.
} 
organs, i.e. for severe burns, spinal injuries and organ transplantation,19, in treatment of the consequences of cerebrovascular accidents (strokes), in the treatment of monogenic or degenerative diseases ${ }^{20}$, as well for diabetes and Parkinson's. ${ }^{21}$

In the present study, we will focus on the importance of the application of therapeutic cloning in transplantations, which promises spectacular results for humans.

\section{Therapeutic Cloning in Transplantations}

Human tissue and organ transplantation can be considered to be one of the biggest achievements of man in the medical field. The inability of organs and tissues to fulfill their natural purposes, due to damage and diseases, makes the application of transplantations a life saving possibility. The aim of transplantations is to sustain the life of the patient and to restore health. This can be achieved through the replacement of a damaged organ or tissue with a healthy one, which the patient receives from a donor.

Transplantations, due to their complexity, raise great moral and legal issues. Consent and the protection of the donor's dignity and rights, the removal of organs even from a deceased donor, the commercialization of human body parts, and the definition of the time of death, are only some of the topics that every country has to deal with on a legislative level.

In what follows, we will examine two of the most basic problems that occur in the transplantation problématique. On the one hand, there is what is called transplant gap; on the other, there is the problem of tissue compatibility of the donor tissues with those of the recipient.

As Adami correctly observes, 'in spite of the fact that transplantations have become a part of our everyday life and even though their results are increasingly satisfactory, we can still observe hesitation and inhibition in free-will offer of transplants, despite the experts' appeals'. ${ }^{22}$ This disproportion between the availability of and the demand

\footnotetext{
${ }^{19}$ Sanchez-Sweatman (n 2) 29.

${ }^{20}$ E Saridakis, Bioethics - Moral issues of new biomedical technologies, (Papazisi, 2008) 165-166.

${ }^{21}$ Byrne and Gurdon (n 7) 154-155.

${ }^{22}$ Varka-Adami, The Law of transplantations, (Ant. N Sakkoula, 1993) 19.
} 
for transplants ${ }^{23}$ is the so called 'transplant gap'. Because the number of organs and tissues available for transplantation is far smaller than the huge demand for them, the system is often unable to provide the transplant to the patient at the crucial moment, leading to the worsening of the patient's health and potentially their death. ${ }^{24}$

But even if the necessary transplant is found, there is still a problem needing to be solved; namely that of compatibility between the donor's organ or tissue and the recipient. A frequent phenomenon in transplantation practice is the rejection of the transplant from the recipient's organism. In order for this to be avoided, immunosuppressive drugs are prescribed to the patient, but these cannot always assure the success of the procedure. As Saridakis remarks, "it is often necessary that the donor has a close genetic relation to the patient, in order for the donor to be examined for tissue compatibility with some possibilities of success'. ${ }^{25}$ The treatment to which the patient must be submitted after the transplantation is conducive to the hibernation of the immune system ${ }^{26}$ and even to the development of cancer. ${ }^{27}$

But how could therapeutic cloning help to solve these two important problems?

Regarding the transplant gap, therapeutic cloning would empower every person to 'create and sustain one's tissue and organ substitutes, by fertilizing ova using the DNA of one's cells and by utilizing these stem cells accordingly, for potential use throughout one's life'. ${ }^{28}$ Hence, the availability of organs and tissues for transplantation will be irrelevant, since the recipient and the donor will be the same person. The currently very difficult matter of finding suitable donor organ would then be invariably resolved. ${ }^{29}$ Thus, the therapeutic cloning method ensures the resolution of the disproportion between the supply and demand of transplant organs and tissues.

\footnotetext{
${ }^{23}$ Atala (n 18) 83.

${ }^{24}$ Savulescu (n 8) 492.

${ }^{25}$ Saridakis (n 20) 164.

${ }^{26}$ ibid.

${ }^{27}$ Garrard Post (n 3) 452.

${ }^{28}$ T Vidalis, Bio-law - Vol.1: The person, (Sakkoula, 2007) 75.

${ }^{29}$ ibid 74 .
} 
The solution of the tissue compatibility problem through therapeutic cloning is based on the fact that the recipient and the donor are the same person. For that reason, the tissues of the embryo which is created through cloning are totally compatible with the recipient's organism, because the genetic material of the embryo is identical to that of the patient. ${ }^{30}$ In the latter part of this essay, we will see how this justifies the use of therapeutic cloning, in the context of Aristotelian philosophy.

\section{The International Legal Status Quo on Cloning}

Cloning is a subject that evokes dissension among countries in respect of public policy and legislation, as well as at the level of international organizations. First, we must keep in mind that reproductive cloning is explicitly prohibited. The differentiation between countries' approaches concerns therapeutic cloning and embryonic stem cell research. Some countries allow therapeutic cloning and research on embryonic stem cells (e.g. United Kingdom, Japan, Belgium, Israel). Others ban therapeutic cloning, but allow research on embryonic stem cells (e.g. France, Germany, Russia). Finally, some countries ban both methods, having expressed their explicit objections (e.g. Italy) and others are yet to legislate on the matter. ${ }^{31}$

Within international organisations, the situation is even less clear. The United Nations' 'Declaration on Human Cloning, 32 in 2005, which was the result of a 4-year debate, failed to achieve its original aim, of banning only reproductive cloning and allowing therapeutic cloning. In a vote on whether both forms of cloning should be prohibited, 84 nations voted in favour, 34 against, with 37 abstaining and 35 absent. As a consequence, both methods of cloning were banned, but without binding legal force. ${ }^{33}$ As far as the Council of Europe is concerned, we have the Convention on Human Rights with regard to Biomedicine ${ }^{34}$, which bans

\footnotetext{
${ }^{30}$ Saridakis (n 20) 165; Savulescu (n 8) 492.

${ }^{31}$ H Bedford-Strohm, 'Sacred Body? Stem Cell Research and Human Cloning', The Ecumenical Review, (2009) Vol. 54, Issue 3243.

${ }^{32}$ United Nations, Declaration on Human Cloning, resolution 59/280.

${ }^{33}$ Vidalis (n 28) 78.

${ }^{34}$ Council of Europe, Convention for the Protection of Human Rights and Dignity of the Human Being with regard to the Application of Biology and Medicine: Convention on Human Rights and Biomedicine, Oviedo, 4.IV.1997,
} 
cloning of human beings, and the Additional Protocol to the Convention on Human Rights with regard to Biomedicine ${ }^{35}$, which specifically prohibits reproductive cloning of humans, while allowing countries to take their own initiatives concerning the subject of therapeutic cloning. With regard to the European Union, a ban of funding for both types of human cloning, therapeutic and reproductive, is in place, nevertheless permitting the member states individually to fund the research on embryonic stem cells, if they can provide the proper guarantees. Finally, UNESCO's Universal Declaration on the Human Genome and Human Rights $^{36}$ points out that reproductive cloning of human beings should not be allowed as it is antithetical to human dignity.

One can easily see that finding the appropriate balance to lead to the acceptance of therapeutic cloning internationally is very difficult. This essay is in support of the view that countries such as the United Kingdom, where therapeutic cloning and embryonic stem cell research is allowed, must play a leading role in the formation of an international consensus, by motivating and encouraging other countries to follow its example. We should not, after all, forget that the conversation on therapeutic cloning began in the British Parliament. ${ }^{37}$

The present study aims to address fears and inhibitions, either justified or unjustified, to therapeutic cloning, and aims to establish the latter on firm moral grounds. Our main starting point will be Aristotelian philosophy, as this focuses on the concept of nature, the role of medicine as an art aimed at health, and the role of practical wisdom in political decision making. The ultimate purpose of the essay is to explore how

$<$ http://conventions.coe.int/Treaty/en/Treaties/html/164.htm> accessed on 24 September 2012.

35 Council of Europe, Additional Protocol to the Convention for the Protection of Human Rights and Dignity of the Human Being with regard to the Application of Biology and Medicine, on the Prohibition of Cloning Human Beings, Paris, 12.I.1998, $<\mathrm{http}$ //conventions.coe.int/Treaty/en/Treaties/html/168.htm > accessed on 24 September 2012.

${ }^{36}$ UNESCO, Universal Declaration on the Human Genome and Human Rights (1997) $<$ http://portal.unesco.org/en/ev.php-

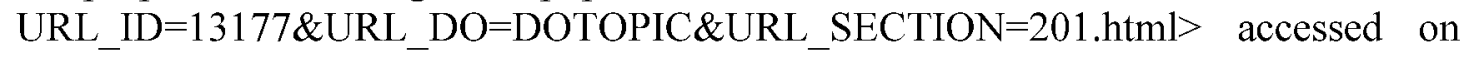
24 September 2012.

${ }^{37}$ Bedford-Strohm (n 31) 246; Alex Sleator, 'The Human Reproductive Cloning Bill [HL], Bill 57 of 2001-02', House of Commons Research paper 01/104, $27^{\text {th }}$ November 2001. 
appropriate legislative measures can be enacted internationally to govern therapeutic cloning.

\section{The Aristotelian Perspective}

\section{Introduction}

The present study aims to illuminate some aspects of the therapeutic cloning problématique through Aristotelian philosophy. This will be accomplished in two stages. Firstly, we discuss the proper understanding of fundamental concepts for our research, namely nature, art and matter. Secondly, with respect to political philosophy, we will see how the Aristotelian conception of practical wisdom is relevant for decision and law making, with respect to our subject. In this way, we will explore the practical significance of our research and demonstrate its relation to questions of moral law and moral politics.

Unavoidably, profound moral questions raise profound moral objections. We consider that therapeutic cloning is situated on the borderline between human nature and human technique. In what follows, we will examine all the moral objections to therapeutic cloning that have been presented through the course of the international debate. We will identify the most fundamental issues, examine their validity and consider how they can be answered. Finally, we will show how political philosophy can play an important role with respect to therapeutic cloning for transplantation, by setting the boundaries of appropriate usage and by supervising the application of this new method.

\section{The Aristotelian Concepts of Nature and Art and their Importance}

Nature ('physis'), on the one hand, provides us with the knowledge of what we can consider as natural. Nowadays, the limits of what is, or what can be considered as natural need to be redefined, due to technological progress. Establishing these limits is now more complex, yet more imperative, than ever. We will therefore consider which are the essential conceptual elements of nature. Finally, we will show in what way health can be considered to be one of the goals of nature. 
Art ('techne'), on the other hand, will be discussed in light of Aristotle's conceptualization of medicine as a form of human art. We will examine the definition of art in Aristotle, the basic kinds of art, their purpose and their hierarchy. We will conclude by examining the status of health as a goal of the medical art.

Having thus conceptualised nature and art, we will use this knowledge in order to show how art complements nature and gets a practical importance on our subject. The interweaving of these two complementary concepts, and their common goals, will be of great importance for the present study.

\section{Nature and "By Nature" Beings}

In this section we discuss how the concept of nature functions in Aristotle, and how this bears upon our study. We need not discuss Aristotle's conception of nature in general, but only that part concerning the nature of beings.

Aristotle observes that: ' $O$ f things that exist, some exist by nature, some from other causes'. ${ }^{38}$ By other causes he means art and luck. 'By nature the animals and their parts exist, and the plants'. ${ }^{39}$ Taking a tree as an example: if we isolate its leaves, its branches, its roots and its trunk, we cannot claim that each one of them separately constitutes a tree. In the example of the tree, the quality that makes it a tree as a whole and not just a bunch of leaves, branches, roots and trunk, is what we call the nature of the tree. We can perceive this by using our senses, through its form ('morphe').

In considering the nature of beings, we take as a starting-point the duality of nature: on the one hand, nature is matter ('ili'), and on the other hand it is form. ${ }^{40}$ Concerning the synthesis of these two, matter and form, Aristotle quotes: 'this is not nature, but a by nature- being as human is'. ${ }^{41}$ By nature are called the beings that consist of matter and form. Form is interpreted as 'the unity and identity of a being ${ }^{42}$ — in other words 'the

\footnotetext{
${ }^{38}$ Aristotle, Physics, 192 b 6-7.

39 ibid 192 b 7-8.

${ }^{40}$ ibid 199 a 33-34.

41 ibid 193 b 7.

42 A Chougias-Palaiologos, Philosophy of Law, 2. The definition of Philosophy of Law, (Ant. N. Sakkoulas 2007) 34.
} 
quality that prevails in it'. ${ }^{43}$ And form, on a first level, seems to be the nature of the being, rather than its matter. ${ }^{44}$ There is still something else that cannot be perceived by our senses, which exists within the being and which is a structural part of it. This is called matter. Matter, in the theory of Aristotle, is something that we cannot comprehend through our senses, if it is not shaped through form. If we could isolate the unshaped matter, separating it from the form, then we could only see a potential being. Returning to the example of the tree, we can say that the seed is not a tree by itself, but it contains the matter of which a tree can be constituted, despite itself possessing neither the shape nor the form of a tree. This constitution is only a possibility at this stage, but if we plant this seed and nothing prevents it from growing, a new tree will be formed.

We can easily understand, without further explanation, that the natural condition of a being in general is life rather than death. Thus, health is human nature's primary goal, in order to maintain itself. That means the prevalence of life over death; in other words, the prevalence of the being over the non-being or of renewal over damage. The essence and the purpose of human nature cannot be easily separated. A being such as a human, in order to sustain its basic quality as a human (its form) must succeed in its pursuit of the goal of health. This does not mean that a patient stops being a human; only by his death does he stop being a human being. However, the procedure that maintains a living being's status as part of nature is the preservation and improvement of the conduct of its functions.

The human being as an organism can fulfill its natural functions when each of the organs separately can perform its function. In the event that this is impossible, it is medicine's duty, through the choice of a particular therapy, to reinstate the normal, natural state of the human organism. That means that medicine should repair the damage and bring back the natural function of the organism. Medicine should assist human nature in achieving its goal, a point to which we return later.

Aristotle argues for a constant procedure of renewal following damage, in connection with the matter of beings. The one succeeds the other; thus, health is at the same time the goal and the point where

\footnotetext{
${ }^{43}$ Aristotle, Physics, 187 b 7-8.

${ }^{44}$ ibid 193 b 15-22.
} 
renewal follows damage, to the extent required in order for the natural functions of the organism to be normally accomplished. Health is the goal of human nature which, as long as it is achieved, ensures the continuation of life of the human being. And this happens because health is the prerequisite for the fulfillment of man's goals.

\section{Art and Medical Art}

Aristotle notices that:

All art is concerned with coming into being, with contriving and considering how something may come into being, which is capable of either being or not being, and whose origin is in the maker and not in the thing made. For art is concerned neither with things that are, or come into being, by necessity, nor with things that do so in accordance with nature, since these have their origin in themselves. ${ }^{45}$

For example, the sculptor, taking an unshaped piece of marble, gives it the form he wants, in order to make a statue. He can make a human statue or an animal statue or whatever he desires. But between the variety of possible forms, he chooses a specific one. At the end of the process, the sculptor himself does not exist in the statue, but it is his expressed will to give a form to the statue, that exists in it in some way.

Art in Aristotle's view, is 'a state concerned with making, involving a true course of reasoning, concerned with the variable'. ${ }^{46}$ In order to understand this concept of art, we must keep in mind the distinction that Aristotle draws between two categories of variable object: those who are produced through making and those who exist through acting. Then, he makes clear that 'making and acting being different, art must be a matter of making, not of acting'. 47

In Physics, he also proposes a partition of the arts into two kinds; into 'the arts which use the product and the arts which direct the production of it'. ${ }^{48}$ As Polansky correctly remarks, 'the usage of arts brings them closer to practical sciences ${ }^{49}$, a point he emphasizes with

\footnotetext{
${ }^{45}$ Aristotle, Nechomachean Ethics, 1140 a 11-15.

46 ibid 1140 a $20-22$.

47 ibid 1140 a $15-17$.

${ }^{48}$ Aristotle, Physics, 194 b 1-2.

${ }^{49} \mathrm{R}$ Polansky, Is medicine a science, an art or practical wisdom?, Bioethics: Ancient Themes in Contemporary Issues, (Travlos, 2007) 92.
} 
respect to medicine, observing that 'once medicine creates health, by helping nature and by using various tools, medicine seems to be both productive and directive art'. ${ }^{50}$

We can thus see why medicine can be considered more as an art than a science, in Aristotle's philosophy. We say that it is an art, because the doctor decides in every particular case what the right thing to be done is, and its results are not predictable, as they are in science. To take an example, suppose that a doctor is treating a patient with heart disease. $\mathrm{He}$ can choose between several kinds of potential treatments such as healthy nutrition, pharmaceutical medication, surgery, transplantation etc., in order to cure his patient. Now, a science such us mathematics, no matter how many times we repeat the same procedure, we always get the same result. But, in the medical art, even if the doctor repeats the same therapy, the result may vary from case to case and from patient to patient. As a consequence, we may consider medicine to be more an art than a science. The Ancients have provided us with an understanding -of medicine as an art which is connected indissolubly with the knowledge of nature ${ }^{51}$, since, for man, art assists him to diminish or to confront the dangers that derive from his mortal nature. As every art aims at a higher good ${ }^{52}$, so does medicine serve the ultimate aim of health. Classical philosophers give medicine a distinct place amongst the arts. ${ }^{53}$ This occurs because health, as we discussed above, is the primary goal and the basis for achieving all the other goals of human nature. However, each doctor does not contemplate this ultimate purpose, but rather the means which he will use in order to achieve it.

We have pointed out that there has to be a balance in the natural organic human functions, in order for the goal of health to be achieved. By the accomplishment of this purpose, the continuation of the individual's existence is ensured. Health, seen as a natural state per se, makes the bond between medicine and human nature indissoluble. In the following section, we further discuss this relationship and the complementarity between nature and art.

\footnotetext{
50 ibid 105 .

${ }^{51}$ ibid. 82.

${ }^{52}$ Aristotle, Nechomachean Ethics, 1094 a 1-2.

${ }^{53}$ Polansky (n 49) 105.
} 


\section{Interweaving of Nature and Art}

Having defined nature and art, and having classified medicine among the arts, we now try to define the role of art in relation to nature and how these two are interweaved. We must clarify from the beginning that in no way is this a conflict between nature and art, nor is it a substitution of one for the other. The fact that art imitates nature, invites us to consider the two as harmonic complementary procedures. In this framework, art does not substitute nature, but rather helps nature by providing additional amenities that are useful for achieving its goals.

Aristotle says that art imitates nature ${ }^{54}$, and goes on to say that the way in which a thing is produced by nature is similar to how it is produced of art and vice versa, if no obstacle emerges. ${ }^{55}$ Therefore, art accomplishes all that nature cannot make, and imitates all the rest. ${ }^{56}$ Hence, we observe that one exists due to the other, and that art fulfills 'whatever nature has failed to provide or provided insufficiently'. 57

In the case of medicine, bringing patient's health back to a balanced state demands the collaboration of nature and medicine. ${ }^{58}$ The aim is for the patient to normally continue his life, or even to have an improved one. Human nature demands the aid of the art which has been set by its side in order to confront powers opposed to life. That is what medical art is about, which according to Gadamer 'entirely introduces itself in nature's procedure, up to the point that is to want to restore this procedure when disturbed, and does it in such a way that art allows itself to disappear right on after natural balance of health has returned'. ${ }^{59}$

Further considering the interaction between nature and art, Aristotle makes a remarkable observation: 'If there is purpose in art, there is in nature as well. The best example is of the human who heals himself. Nature looks like him'. ${ }^{60}$ This particular acknowledgement will be a focal point towards understanding the problématique of therapeutic cloning as a

\footnotetext{
${ }^{54}$ Aristotle, Physics, 194 a 25.

${ }^{55}$ ibid 199 a 9-10.

56 ibid 199 a $16-17$.

${ }^{57}$ Polansky (n 49) 93.

58 ibid 115.

${ }^{59} \mathrm{H}$ G Gadamer, The Enigma of Health, (Stanford University Press, 1996).

${ }^{60}$ Aristotle, Physics, 199 b 33-36.
} 
tool in transplantations; we will work towards this conclusion by examining the concept of matter in Aristotle.

\section{Matter in Aristotle - One's Own Matter: the Key to Self-Healing}

Previously, in talking about the concept of nature, we touched upon the concept of matter. We will now consider the crucial role of this concept in discussing therapeutic cloning for transplantations.

According to Aristotle, the nature of matter is such that 'it needs to exist before it is born'. ${ }^{61}$ Matter is itself undefined, unshaped, unknown and infinitely divisible ${ }^{62}$ and the only way for it to be perceived by our senses is as the 'own matter ${ }^{63}$ that constitutes some entity' and moreover already shaped by form. ${ }^{64}$ For example, the atom is matter, but we cannot perceive it by our naked sense of sight. That's why we need powerful microscopes in order for this to be done.

But what is the matter of man and how can we get to know it? We have seen that the nature of a 'by nature' being is, first and fore-most, its form. Its matter, however, must be further analysed and we must explain the concept on which we will later on refer to as own matter. In order for this to be understood, we must first explain what is what we call 'own or closest genre'. ${ }^{65}$

Own or closest genre is what we can call the common formed matter of a group of beings. ${ }^{66}$ For example, own genre is the one of mammals, which differentiates them from the rest of the categories of animals (mammals are different from birds). Own matter, is a common matter to a specific distinction within a genre. For example, it is what distinguishes man from any other mammal and is common between all beings that share human status (man is different from cat). The last specification of own matter is what we call one's own matter ${ }^{67}$, meaning each individual's own matter separately. This last kind of matter will be the one that we discuss here.

\footnotetext{
${ }^{61}$ ibid 192 a 36-37.

${ }^{62}$ Chougias-Palaiologos (n 42) 31.

${ }^{63}$ ibid 41.

${ }^{64}$ Aristotle, Metaphysics, 1029 a 20.

${ }^{65}$ Chougias-Palaiologos (n 42) 32.

${ }^{66}$ ibid 34 .

${ }^{67}$ ibid 41.
} 
Apart from the general characteristics that give a being its human quality, there is also something unique to the genetic material of each human that makes him different from all the rest of his kind. For example, what makes John different from Mark? The last specific distinction or, in other words, one's own matter, is nothing other than one's genetic material. This is the specific distinction that gives each human being a unique identity among all others - that makes a human being special amongst all others. One's own matter seems to be encapsulated in a stem cell. This contains not only the genetic material that classifies the individual as of the human kind, but, moreover, the specific material that makes him the specific human that he is.

In transplantation cases Chougias observes 'the phenomenon of the rejection of the transplant often occurs, because one's own matter is not the same as the transplant ${ }^{68}$ If we could, therefore, find a medical method that would solve the problem of own matter in transplantation we would accomplish two things. Firstly, it would ensure the non-rejection of the transplant. Secondly, it would enable the non-use of immunosuppressive drugs, which are prescribed in order for the transplant not to be rejected, and which are also responsible for the hibernation of the immune system and the risk of carcinogenesis to the patient.

The medical method that can be utilised to satisfy the above requirements and to use the own matter of each patient is therapeutic cloning. Through the use of one's own matter, i.e. the patient's genetic material which can be found in his stem cells, the patient can achieve self-healing. ${ }^{69}$ The creation of an embryo-clone from the healthy cells of a patient, as a source of embryonic pluripotent stem cells, makes the tissues of the embryo automatically compatible with the patient's organism. ${ }^{70}$ Hence, the problem of tissue compatibility ceases to exist, and so the prescription of immunosuppressive drugs to the patient is unnecessary. We therefore observe that the donor and the recipient of the transplant is the same person on the basis of Aristotle's theory regarding matter.

\footnotetext{
${ }^{68}$ Chougias-Palaiologos (n 42) 41.

${ }^{69}$ Aristotle, Physics, 199 b 33-36.

${ }^{70}$ Saridakis (n 20) 165.
} 


\section{Practical Wisdom and Politics}

Aristotle states that the 'ends of the master arts are to be preferred to all the subordinate ends; for it is for the sake of the former that the latter are pursued'. ${ }^{71}$ The hierarchy of arts comes under politics. For Aristotle, politics is considered to be the "master and authoritative, ${ }^{72}$ art. Politics should 'guide all other arts and single out in which cases must these be used or not'. ${ }^{73}$ The right way of use of the arts should be dictated by rationality, which is set by an intellectual virtue, according to Aristotle. This virtue is called practical wisdom ('phronesis').

Practical wisdom for Aristotle is 'a reasoned and true state of capacity to act with regard to human good'. ${ }^{74}$ Thus, practical wisdom allows us to choose the right means for accomplishing a purpose, in respect of human actions. ${ }^{75}$

Practical wisdom refers to everything that has to do with human things which are objects for decision. ${ }^{76}$ Aristotle observes that 'if, then, it is characteristic of men of practical wisdom to have deliberated well, excellence in deliberation will be correctness with regard to what conduces to the end of which practical wisdom is the true apprehension'. ${ }^{77}$ Practical wisdom is the virtue that makes us choose how to act according to the analogy between the means and the ends. Hence, the means for achieving the ends of politics should be chosen by practical wisdom.

The purpose of politics and practical wisdom according to Polansky is 'blissful life, but opposite to the purpose of art -which makes a product or promotes an external result- this choice itself and the doing of right things consitutes blissful life'. ${ }^{78}$ Bliss ('eudemonia') is, according to Aristotle, 'a kind of energy of the soul that is present due to virtue'. Bliss, as he observes, lies in the fact that 'we must lose our mortal nature

\footnotetext{
${ }^{71}$ Aristotle, Nechomachean Ethics, 1094 a 15-16.

72 ibid 1094a 26-28; Aristotle, Physics, 194 b 1-2.

${ }^{73}$ Polansky (n 49) 96; Aristotle, Nechomachean Ethics, i 1-2.

${ }^{74}$ Aristotle, ibid, 1140 b 4-6.

${ }^{75}$ ibid 1141 b 21.

${ }^{76}$ ibid 1141 b 8 .

${ }^{77}$ ibid 1142 b 30-32.

${ }_{78}^{78}$ Polansky (n 49) 101.

${ }^{79}$ Aristotle, Nechomachean Ethics, 1099 b 27.
} 
as much as possible and aim at immortality'. ${ }^{80}$ From this last important observation, we conclude that within the borders of what is humanly feasible, and by particularising the problématique of the present study, health is the basis of bliss. In other words, well-living is essential for well-acting.

Politics' final goal is the bliss of political society and this can be accomplished through practical wisdom, which singles out the right way of using the arts. We have established that medicine, of all the arts, is the one that most closely complements the fundamental aim of human nature, namely health. Since the purpose of medicine is health and since politics, as an authoritative art, should assist medicine to fulfill this purpose, then health is an indirect purpose of politics as well. Furthermore, since health is the basis of bliss, health is once more the purpose of politics. The mortal human nature needs practical wisdom in order to choose, at a societal level, which medical methods are appropriate as the means for achieving the goal of health. We will see analytically, further down, how this can be done practically as we focus on the problématique of therapeutic cloning, and proceed into critical analysis of the main objections concerning this method.

\section{Moral Objections to Therapeutic Cloning}

Having discussed all of the Aristotelian concepts that enable us to conceptualise the problématique of therapeutic cloning, we turn to the classification of moral and other objections to therapeutic cloning.

The first and most primary of objections against the method of therapeutic cloning is the fact that it is condemned by many as unacceptable experimentation. This utterance can be divided into two parts: a) moral-law status of the embryo and b) respect for the dignity of the woman-donor of the ova.

Regarding the first part, the question of when a human life begins has become an international topic for discussion within law, science and ethics. Vidalis notes that: 'the set term that research is usually interested in, is restricted to the first fourteen days from the ovum's fertilization and even more when the embryo is outside of the woman's body (embryo in

${ }^{80}$ ibid 1177 b $33-34$. 
vitro)' ${ }^{81}$ This is because until the 14 th day 'there is a possibility that the embryo will divide into twins, and therefore the individuality of the embryo is seen as beginning only after this period'. ${ }^{82}$ We have seen that during therapeutic cloning method the embryo is destroyed after the pluripotent stem cells are isolated, which can constitute the matter for creating tissues and organs for transplantation. It is possible to collect the pluripotent stem cells from the 6th to the 14th day from SCNT. Until the 14th day of their fertilization, stem cells have the ability of differentiating themselves into all the other cell types. ${ }^{83}$

There remains disagreement on whether the embryo is a potential human being and on whether it is considered to have the status of a person. The disagreement reflects different nations' attitudes towards the legal status of embryos and towards the moral status that is attributable to them. In the author's opinion, we cannot talk about the embryo as a human being, but rather as matter as discussed earlier. Hereby adopting an Aristotelian understanding of morality, it is submitted that, with regard to the moral status of the embryo, one should approach it as matter in the Aristotelian sense of the term, rather than as a human being. In light of this, this essay endorses the opinion expressed by Warnock's Committee, which states that the embryo alters its moral status throughout its period of development ${ }^{84}$, without this implying that the embryo is equated to a complete human being. ${ }^{85}$ At the opposite end of the spectrum, the Catholic Church equates the embryo to a person and considers it to be a complete human being from the moment of its conception. ${ }^{86}$ As widely accepted as this argument is, one should also, at this point, keep in mind, that the destruction of embryos can occur in other biomedical applications as well, such as in vitro fertilization or abortions.

If we focus on the therapeutic benefits of the transplants to recipients, and if it is endorsed on a national and international level that the destruction of the embryo until the 14th day from conception is not

\footnotetext{
${ }^{81}$ Vidalis (n 28) 76.

${ }^{82}$ Bedford-Strohm (n 31) 248.

${ }^{83}<$ http://www.bioethics.gr/document.php?category_id=69\&document_id=311> accessed on 24 September 2012.

${ }^{84}$ Savulescu (n 8) 495.

${ }^{85}<$ http://www.hfea.gov.uk/docs/Warnock_Report_of_the_Committee_of_Inquiry_int o_Human_Fertilisation_and_Embryology_1984.pdf $>$ accessed on 24 September 2012.

${ }^{86}$ Savulescu (n 8) 494.
} 
the same as the destruction of a human life, but rather of a potential human life, then consensus can be reached at a political and legislative level. Thus, we consider that in this particular case, the basic Hippocratic principle of medicine 'help, or do no harm' applies, and that therapeutic cloning concerning transplantations will be a huge advantage for medicine, and for preserving the continuity of and re-establishing the natural course of human life.

A second condemnation of therapeutic cloning as unacceptable experimentation, pertains to the status of the female donor of ova. We noted that therapeutic cloning requires not only the genetic material from the donor's stem cells, but also an ovum into which the nucleus of the cell will be transferred. Many talk about how this is an insult to the dignity of the woman-ovum donor, as they are claiming that she is being reduced to nothing but an ovum donor. ${ }^{87}$ Yet, what should be acknowledged is that this is not the case, as the donation takes place with the woman's full consent and expression of free will. From this point onwards, it is the duty of each country to prevent commercialization and financial exploitation of the ova. However, especially in light of the fact that the success rate of the method remains low, and thus a great number of ova are required. On a level of political will, our suggestion is to encourage volunteering through organized and targeted information or even through education concerning the meaning of ovum donation, putting emphasis on the benefits of the method of therapeutic cloning for transplantation. In our opinion, not only is the woman-donor's dignity not insulted, but also the social right to health is promoted by such means.

A second objection concerning the method of therapeutic cloning has to do with the danger of slipping over into reproductive cloning. The goals of these two kinds of cloning differ. It is clear that the purpose of reproductive cloning is the creation of a new self contained human being, while the purpose of therapeutic cloning is solely the production of organs and tissues for transplantation. Nevertheless, the danger exists, on account of the totipotency and pluripotency of stem cells; for example, a research team in a lab might aim to take advantage of the stem cells' totipotency and attempt to create a self-contained human organism.

Undeniably, it is very difficult to control medical research in such a

${ }^{87}$ D Psaroulis, P Voultsos, Medical Law, (University Studio Press, 2010) 184. 
competitive sphere. Researchers strive constantly to present pioneering results. However, researchers worldwide have to agree on a common moral and practical code of ethics regarding medical research, in order to promote the use of the method of therapeutic as opposed to reproductive cloning, weighing up the big advantages of the former against the possible negative consequences of the latter. It must become clear that the danger of therapeutic cloning slipping into reproductive, is itself not a sufficient reason to deprive society of the potential benefits of the former important method. Clearly such an agreement cannot solve the problem by itself; political and legal support is required. In our opinion, this is a matter of political will, in that the passing of suitable laws and the maintenance of adequate enforcement, effectively penalising offenders, can succeed in preventing violations of this code.

A third objection to therapeutic cloning is the uncertainty regarding the reliability of the method. Success rates for cloning which aims at creating stem cells are still quite low. Nevertheless, it is anticipated that political decisions leading to adequate funding of the method, will eventually produce the desired outcome. In the future, it is reasonable to anticipate that the development of therapeutic cloning will render this method as effective as transplantations, as we know them today. Furthermore, possible complications in the recipient's organism arising from the transplantation of cloned material are considered as a disincentive by some. ${ }^{88}$ Theory, however, speaks to the exact opposite and we should also point out that this kind of fear exists in every modern medical method and does not, in any case, justify the prohibition of therapeutic cloning. Also, some question the tissue compatibility of the transplant. According to medical evaluations, tissue compatibility is considered to be a given, and has a better chance of success than in the case of a transplant from another donor, as observed in our discussion of the concept of the subject on one's own matter.

A fourth objection to therapeutic cloning pertains to the "unnatural" aspect of the method. Some claim that humanity tries to usurp the role of nature in general, through the method of cloning and in particular through therapeutic cloning. We have already showed what nature is, what its purpose stands as, and how therapeutic cloning as a medical

88 ibid. 
method completes human nature by aiming at the patient's health. We have also highlighted the therapeutic benefits of the specific method, thus tying it to the fundamental purpose of human nature, which is none other than health.

The fifth and final objection we consider concerns the danger of commercialization of human tissues and organs, which will be produced through therapeutic cloning. One can easily comprehend that such a thing is equally possible in the field of transplantations as done nowadays. However, we consider that therapeutic cloning will not only not intensify the problem of commercialization of organs for transplantation, but will rather limit it as well. This remains a matter which needs to be handled by the legislator, and it is up to him to institute the right laws and to create the proper controlling mechanisms, in order to prevent such occurrences. Polansky says that: 'Every art that has a relatively narrow field, can be guided by a greater insight of the human good in relation to when and how this should be executed'. ${ }^{89}$ Medicine, as shown above, is such an art indeed, and the right way of use of its methods is specified by politics as much at the level of political decisions, as in the formulation of laws relevant to these methods.

Therefore, a criterion should exist, which will guide us towards the right means to use medical applications. Therapeutic cloning for transplantations is such an application of medicine, and the criterion is politics through practical wisdom.

\section{Conclusions}

Creating consensus regarding the matter of whether therapeutic cloning should be allowed, relies upon finding common grounds of understanding between countries. For this to be accomplished, countries should redefine some of their moral values, by keeping in mind the benefits of the human lives that will be saved through the transplantations. The promotion of these ideals should be undertaken by governments, committees and civilian organisations, which through their cooperation will examine and address the moral objections to therapeutic cloning within a framework of rationalism. The aim of this dialogue will be on the one hand to avoid the demonisation of therapeutic cloning as a medical application, and on the

${ }^{89}$ Polansky (n 49) 122. 
other hand to underline the benefits that are promised for human health.

Thus, an emphasis should be placed on establishing the right way to use the therapeutic cloning method, a procedure that demands negotiation from all sides, in order for a final agreement to exist regarding its international application.

We have already established that therapeutic cloning provides a solution for the tissue compatibility issue in transplantations, and contributes to resolving the imbalance between demand and supply of transplantable tissues. Generally speaking, we must emphasise that two important parameters in the creation of a functional framework for therapeutic cloning, are the provision of sufficient funds and resources for developing the method, coupled with enforcement of legal regulations concerning cloning. All of the previous points, however, are subject to political decisions.

This essay has focused extensively on the substantial role that Aristotelian philosophy can play in this discussion. Aristotle's philosophy is so penetrative and ethically concrete that it can provide a moral compass for navigating through such a modern and complex field as therapeutic cloning. Moreover, we have seen how the link between therapeutic cloning and Aristotelian ethics has enlightened the practical dimension of the subject.

It is hereby advanced that therapeutic cloning should indeed be allowed worldwide. The advantages which are promised by therapeutic cloning in the field of transplantations constitute an immediate and imperative purpose of human society. Health, as we have examined, is the goal of both nature and medicine. As a common purpose of human nature and medicine, health is a fundamental ingredient of bliss, and politics, through practical wisdom, empowers us to choose correctly the means for achieving it. Therapeutic cloning is such a means. 